\title{
Epigrafi Araştırmalarında Yeni Bir Belgeleme ve Analiz Metodu Olarak RTI
}

\author{
RTI as a New Documentation and Analysis Method \\ in Epigraphical Studies
}

\begin{abstract}
Aykan AKÇAY*
Öz: Günümüz teknolojisinin hızlı ilerleyiși sayısal görüntüleme metotlarına ivme kazandırmıș ve kültürel miras araştırmalarına da yeni yaklaşımlar getirmiştir. Teknolojinin bilime sunduğu yeni belgeleme ve analiz metotları birçok disipline adapte edilerek araştırmaların detaylı ve hızlı bir biçimde yapılmasına imkan tanımaktadır. Burada sunulan çalışma son yıllarda kültürel miras araştırmalarında kullanılan Yansıtma Dönüşümlü Görüntüleme (Reflectance Transformation Imaging - RTI) metodunun epigrafi araştırmalarında yazıtların belgeleme ve analiz süreçlerine sunduğu yenilikleri incelemektedir. RTI, bir nesne yüzeyinin farklı açılardan aydınlatılmasıyla elde edilen görüntü verilerinden sentezlenen yansıtma değerlerini kullanarak nesne yüzeyinin mikro-topografyasını ortaya çıkaran sayısal bir fotoğraflama metodudur. Özellikle tahribata uğramış arkeolojik eserlerin yüzey detaylarının belgelenmesinde ve yorumlanmasında ya da yazıt taşıyıcısı yüzeyindeki aşınmış harflerin karakterize edilmesinde görsel algıyı artırarak analiz süreçlerine pozitif katkılar sunmaktadır. Çalışmada 'tahribatsız' belgelemeye ve çok yönlü analize imkan veren RTI metodunun teknik ardalanı ve çalışma prensipleri Phaselis epigrafi araştırmalarında yürütülen $R T I$ çalışmalarından sunulan örnekler ışığında detaylı bir biçimde aktarılmıştır.
\end{abstract}

Anahtar sözcükler: RTI, Kültürel Miras, Dijital Epigrafi, Phaselis, Belgeleme, Analiz

Abstract: Today's advanced technology has accelerated the use of digital imaging methods and brought new approaches to cultural heritage research. The new documentation and analysis methods have been adapted to various disciplines; which has made quick and detailed research possible. This study examines the innovations in documentation and analysis of the inscriptions in epigraphy through the RTI (Reflectance Transformation Imaging) method which has recently begun to be employed in cultural heritage in recent years. RTI is a computational photographic method that records the micro-topography of the surface of an object by using reflectance properties synthesised from the image data that obtained through illuminating the object's surface from different angles. The method has contributed in particular to documenting and for accuracy in commenting upon partially destroyed surfaces of archaeological artifacts; and in enabling the characterisation of the letters of the damaged surface of an inscription bearer, through increasing the definition of the visual evidence. The study presents the technical background and the working principles of the RTI method which enables multi-directional analysis and a documentation process in a 'non-destructive' way, through a consideration of the examples of RTI studies conducted in epigraphical research at Phaselis.

Keywords: RTI, Cultural Heritage, Digital Epigraphy, Phaselis, Documentation, Analysis

\footnotetext{
*Arş. Gör., Akdeniz Üniversitesi, Akdeniz Uygarlıkları Araştırma Enstitüsü, Antalya. aykanakcay@akdeniz.edu.tr Burada sunulan çalışma Akdeniz Üniversitesi, Akdeniz Uygarlıkları Araştırma Enstitüsü, Akdeniz Eskiçağ Tarihi Anabilim Dalı bünyesinde Prof. Dr. Murat ARSLAN danışmanlığında hazırlanan "Kültürel Miras Araştırmalarında Kullanılan Yeni Teknolojik Yaklaşımlar: Phaselis Yazıtları Örneği” başlıklı Yüksek Lisans Tezi’nden yararlanılarak hazırlanmıştır. Çalışma, Akdeniz Üniversitesi, Bilimsel Araştırma Projeleri Koordinasyon Birimi tarafından SYL2015-920 no'lu proje kapsamında desteklenmiştir.
} 


\section{Giriş}

Son yıllarda görüntüleme teknolojilerindeki ilerlemelerle birlikte, kültürel miras araştırmalarında kullanılan dijital belgeleme ve analiz metotlarında yeni yaklaşımlar kullanılmaya başlanmıştır. Nesnelerin hassas üç boyutlu görüntü verilerinin elde edilmesinde kullanılan, saniyede milyon nokta atımı yapabilen 3B lazer tarama teknolojileri ya da piksel bazlı görüntü eşleştirme algoritmaları kullanan sayısal fotogrametrinin yanı sıra, nesne yüzeyine ait mikro-topografik verilerin ortaya çıkarılmasını sağlayan Yansıtma Dönüşümlü Görüntüleme -RTI- gibi teknolojinin bilime sunduğu yeni görüntüleme metotları, kültürel miras araştırmalarında belgeleme ve analiz süreçlerine pozitif katkılar sağlamaktadır.

Materyal kültür kalıntılarının dijital teknolojiler kullanılarak belgelenmesi ve bu alanda çalışmalar yürüten bilim insanları tarafından analizlerinin yapılması yakın geçmişe kadar çok yaygın değildi. Bunun en önemli etkenleri, kullanımı karmaşık cihazlar/yazılımlar ve yüksek bütçe gerektiren ekipmanlardı. Bu nedenle araştırmacılar hizmet alımı yaparak veya alanda uzman kişilerden yardım alma yoluna giderek dijital belgeleme metodolojilerini uygulayabilmekteydi. Günümüzde ise internet aracılığıyla birçok kaynağa erişim sağlanarak bilimsel araştırmalarda kullanılan yeni yaklaşımlar hakkında bilgi sahibi olmak ve bunları uygulamak mümkün hale gelmiştir. Teknolojinin her geçen gün gelişmesiyle, kullanımı zor olmayan 'kullanıcı dostu' programların ve elde edilebilir düzeyde düşük bütçeli ekipmanların artmasıyla araştırmacılar alanlarında yeni teknolojik yaklaşımları uygulayabilmektedirler.

Kültürel miras araştırmalarında; arkeoloji, epigrafi, paleontoloji, antropoloji etc. farklı disiplinlerde eskiçağ bilimlerine yönelik yürütülen sayısal belgeleme ve analiz çalışmalarında üç boyutlu lazer tarama, fotogrametri ve RTI gibi yeni görüntüleme metotları uygulanarak, eserlerin hassas ve yüksek doğrulukta matematiksel modelleri oluşturulabilmektedir. Böylelikle 'sanal koruma' altına alınan eserlerin 'gerçek temsili' olan dijital kopyaları üzerinde görsel algının artırılması analiz sürecine pozitif katkı sağlamaktadır. Bununla birlikte sayısal görüntüleme metotları ile yürütülen belgeleme ve arşivleme çalışmaları, her geçen gün yok olma tehlikesiyle karşı karşıya kalan maddi kültür varlıklarının gelecek nesillere aktarılmasında önemli rol oynamaktadır.

Epigrafi araştırmalarında, antikçağdan günümüze ulaşan yazıtların yüzeyinde oluşan süreç bağımlı, doğal ve beşeri aşındırmalar, epigrafik belgelerin deşifrasyon süreçlerini zorlaştırmaktadır. Bu durum bazı yazıtların analiz sürecinde hatalı okumalara neden olabilmekte ya da deşifrasyonu imkansız hale getirebilmektedir. Bu çalışmada yeni bir belgeleme ve analiz aracı olarak RTI metodu, epigrafi özelinde örnek çalışmalar ışığında mercek altına alınmaktadır. Metodun gelişimi, altyapısı, kayıt yöntemleri ve analiz aşamasına sunduğu görütünleme seçenekleri detaylı olarak aktarılmaktadır. Bilinen kayıt ve analiz yöntemlerinin yetersiz kalabileceği durumlarda, yüzeyi tahrip olmuş, okunmasında zorluk çekilen, okunamayan veya yanlış deşifre edilen yazıtların 'tahribatsız' belgelenmesine ve çok yönlü analizine imkan veren RTI metodunun epigrafi çalışmalarına sağladığı katkılar üzerinde durulmaktadır. Bununla birlikte geleneksel epigrafi çalışmalarına yeni bir bakış açısı kazandırmak ve ileride yapılacak araştırmalara sistemli, sürdürülebilir bir çalışma zemini hazırlamak burada sunulan çalışmanın amaçları arasindadir.

\section{Epigrafi Araştırmalarında Kullanılan Metotlar ve Sorunlar}

Epigrafik çalışmalarda, bilinen araştırma yöntemlerine bakıldığında, tradisyonel yöntemlerin kullanılageldiği gözlemlenmektedir. Yazıtlar yerinde 'görülebilen' veriler 1şı̆̆ında incelenerek okunmaya/deşifre edilmeye çalışılmakta, yazıt taşıyıcısı ile ilgili bilgiler kartotekslere işlenerek 
kaydedilmektedir. Bununla birlikte 19. ve 20. yüzylllarda ise estampaj ya da lateks kullanılarak yazıtların kopyaları çıkarılmaya başlanmıştır. Özellikle 20. yüzyıldan itibaren, fotoğraflama yöntemlerinin (monokrom, mikrofilm, dijital fotoğraflama etc.) belgeleme ve envanterleme çalışmalarında ön plana çıktığı ve günümüzde yürütülen çoğu kültürel miras araştırmalarında olduğu gibi epigrafi alanında da en çok tercih edilen kayıt yöntemlerinden biri olduğu görülmektedir.

Günümüzde estampaj ile örnekleme epigraflar tarafindan yaygın olarak uygulanmaktadır. Estampaj kopyaların elde edilmesi için lifli yapıya sahip özel bir kağıt kullanılmaktadır. Kopyası çıkarılacak yazıtın yüzeyindeki yosun, liken, toprak etc. oluşumlar firça ile temizlenerek yüzeyin pürüzü giderilmekte ve yazıta kazınmış harf gözeneklerinin boşaltılması sağlanmaktadır. Ardından estampaj kağıdı yazıtı kaplayacak şekilde yerleştirilerek 1slatılmakta ve yüzeye uygulanan firça darbeleriyle harf girintileri kağıt üzerine işlenmektedir. Kağıt kuruduktan sonra yüzeyden sökülerek yazıtın negatif bir kopyası elde edilmektedir (Woodhead 1981, 78-83; Keppie 1991, 40; McLean 2002, 67-73). Böylelikle epigraflar yazıtların deşifrasyonu sürecinde estampajlar üzerinden okumalarını yapabilmektedirler. Estampaj uygulamaları, korunma durumu hassas olan yazıtlar için bazı durumlarda tehdit oluşturabilmektedir. Yüzeyinde kırık/çatlak bulunan, aşınmalardan dolayı hassas durumda olan yazıtların 'temas' edilerek kopyalanması ve firça darbelerine maruz kalması, istenmeyen sonuçlara sebep olabilmektedir. Bununla birlikte antikçağdan günümüze orijinal renkleriyle az sayıda ulaşan bazı yazıtların estampaj/lateks uygulamaları, yüzeyde bulunan renk pigmentlerine zarar verebilmektedir. Ayrıca arşivlenen estampajların 1slanma, yırtılma, ezilme, silinme, haşerat tarafindan yenme gibi potansiyel risk faktörleri göz önünde bulundurulduğunda kopyalanan yazıta dair işlenmiş verileri kaybetme olasılığ 1 bulunmaktadır. Bu noktada mevcut estampajların sayısallaştırılması ve arşivlenmesi sağlanarak dijital ortamda muhafaza edilebilmektedir.

Kültürel miras araştırmalarında yaygin olarak tercih edilen belgeleme metotlarından biri olan fotoğraflama, epigrafi araştırmalarında da hızlı ve pratik bir kayıt yöntemi olarak kullanılmaktadır. Bunun yanında özellikle arazide fotoğraf kaydı yapılan yazıtlarda dış ortam şartlarının getirdiği bazı kısıtlamalar mevcuttur. Gün 1şı̆̆ 1 altında fotoğraflanan yazıtlarda 1şık, yazıt yüzeyinin algılanma düzeyine etki eden önemli bir unsurdur. Güneş 1şınlarının yazıt yüzeyine direkt düştüğü durumlarda, harf karakterlerinin
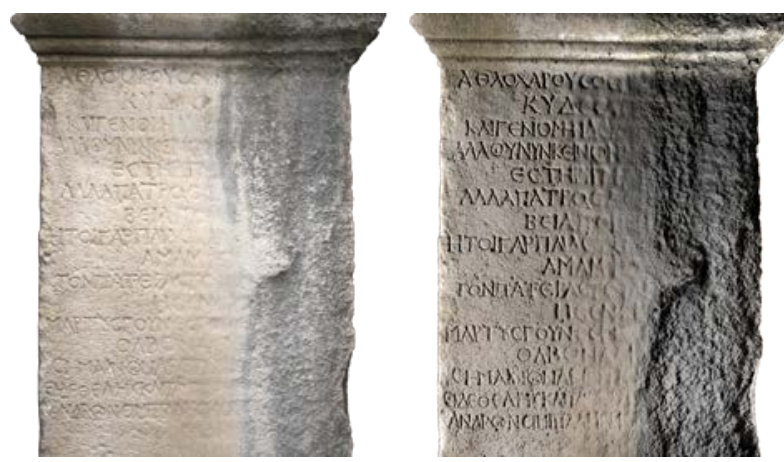

Fig. 1. Işı̆̆ın yazıt yüzeyine direkt düştüğü açıdan kaydedilen fotoğraf görüntüsü ile $R T I$ görüntüsü arasında, karakterlerin algı düzeylerinin karşılaştırılması (Phaselis) işlendiği insizyonların, özgölgeleme oluşturamaması kaydedilen fotoğrafta analize imkan verecek bir görüntü sunamamaktadır (Fig. 1). Özellikle mermer yazıt taşıyıcıları, güneş 1şığının kuvvetli olduğu durumlarda beyaz, parlak bir blok olarak algılanabilmekte ve deşifrasyonu zorlaştırmaktadır.

Tahribata uğramış yazıtların analiz çalışmalarında fotoğraflar üzerinden ya da direkt gözlemle yüzeydeki tüm karakterlerin algılanması zor olabilmektedir. Bu durumda gerek müzelerde gerek arazide bulunan yazıtların fotoğraf ile belgelenmesinde, epigraflar düşük rölyef veya insizyonların algılanabilmesi için yanal 1şık yöntemine başvurmaktadır. Söz konusu yöntemde yazıt yüzeyine düşük açılardan ışık uygulanarak bir dizi fotoğraf kaydı yapılmaktadır. Yatay olarak gelen 1şığın yüzeydeki karakterler üzerinde gölgelenmeler meydana getirmesiyle 
algılanması zor detayların ortaya çıkarılması amaçlanmaktadır. Fakat bu yöntemle yazıt yüzeyi sınırlı açı ve yönde aydınlatılacağı için bazı noktalar aydınlanırken diğerleri gölgede kalacak ve yüzeye ait tüm detayların ortaya çıkması sağlanamayacaktır.

Epigrafi çalışmalarında yazıtlarn belgelenmesinde izlenen yöntemlerin yetersiz kaldığı durumlar ve ortaya çıkan sorunlar göz önünde bulundurulduğunda; tahribata uğramış okunmasında güçlük çekilen ya da korunma durumu kritik olan yazıtların belgelenmesinde alternatif kayıt yöntemlerinin gerekliliği ortaya çıkmaktadır. Eserlere temas etmeksizin 'tahribatsız' belgelemeye ve çok yönlü analize imkan veren RTI metodu, yukarıda bahsedilen sorunlara çözüm sunabilen alternatif bir metot olarak ön plana çıkmaktadır.

\section{Yansıtma Dönüşümlü Görüntüleme - RTI -}

Yansitma Dönüşümlü Görüntüleme (Reflectance Transformation Imaging - RTI), nesne yüzeyinin belirli açılardan aydınlatılmasıyla elde edilen görüntü verilerinden sentezlenmiş yansıtma değerlerini kullanarak, nesne yüzeyinin mikro-topografyasını ortaya çıkaran sayısal bir fotoğraflama metodudur (Mudge et al. 2006, 196). RTI görüntüleri dijital fotoğraf makinesiyle, sabit noktadan kaydedilen bir dizi (24-60) fotoğraftan oluşmaktadır. Kaydedilen her bir fotoğraf karesinde, nesne yüzeyi 'bilinen’ farklı açılardan aydınlatılmaktadır. Işığın materyal üzerinde meydana getirdiği aydınlanma ve gölgelenme verileri RTI oluşturma yazılımı ile hesaplanarak her bir piksele renk değerlerinin yanı sıra yansıtma değerleri de (normal vektörleri) kaydedilmektedir. Bu yansıtma değerlerinin matematiksel olarak sentezlenmesi sonucunda nesnenin hassas ve doğru bir yüzey modeli oluşturulmaktadır (Cultural Heritage Imaging 1a).

Elde edilen model interaktif olarak analize imkan sağlamaktadır. RTI görüntüleme programının sunduğu görüntüleme filtreleri uygulanarak, araştırmacı materyalin analiz sürecinde, ışığı herhangi bir açıdan manipüle edebilir ve incelenecek noktaların yüzey detayı algısını güçlendirebilmektedir (Earl et al. 2010, 2043). Söz konusu metot sadece nesne üzerinde 1şığ1 farklı açılardan uygulayabilmekle sınırlı kalmayıp aynı zamanda elde edilen matematiksel modelin topografik verilerine bağlı kalarak yüzeyin yansıtma değerlerini değiştirme özelliğine de sahiptir. RTI görüntüleme yazılımı üzerinde çeşitli matematiksel filtreler uygulanarak, nesne yüzeyindeki rölyef ve insizyonlar arasındaki karşıtlığı dönüştürmek, yüzeye düşen 1şığın şiddetini veya geliş yönünü ayarlamak mümkündür. Metodu güçlü kılan önemli özelliklerden biri de, incelenen materyalin renk değerlerinin azaltılabilmesiyle nesnenin kendi renklerinden arınmas1nın sağlanması ve sadece yüzey dokusunun ortaya çıkmasıyla görsel algının güçlendirilmesidir (Schroer 2012, 39).

\section{Metodun Teknik Ardalanı ve Gelişimi}

RTI metodunun alt yapısını oluşturan Polinomal Doku Haritaları (PTM), 2001 yılında Hewlett Packard Laboratuvarları (HP Labs) araştırmacıları tarafından bilgisayar ortamında üç boyutlu, foto-gerçek yüzey dokuları elde edebilmek amacıyla geliştirilmiştir. Araştırmacılar, anlık aydınlanma yönünü gösteren bir fonksiyon kullanarak, bir görüntüde bulunan her bir piksel için luminans bilgisini tanımlayan matemiksel bir model sunmuşlardır. Bu fonksiyon ile her bir pikselde saklanan veride; yüzey yansışması, yüzeyaltı yayınması ve özgölgeleme verileri kaydedilmektedir (Malzbender et al. 2001, 521). Tradisyonel görüntü dosyaları ise her bir pikselde sadece renk bilgilerini (RGB) barındırmaktadır. Bir PTM verisinde nesnenin yüzey normalleri de RGB renkleriyle birlikte her bir piksele kaydedilmektedir. Yüzey normali, düz bir yüzeyde bulunan ve yüzeyle kesiştiği noktadan geçen tüm doğrulara dik bir vektördür. Eğer yüzey düz değilse vektör, yüzeye o noktada teğet olan yüzeye diktir. RTI görüntüsünde bulunan her bir normal değeri nesnenin yüzeyinde bir noktaya tekabül etmektedir ve o noktaya düşen 1şığın yansıtma açısını kaydetmektedir (Fig 2). 

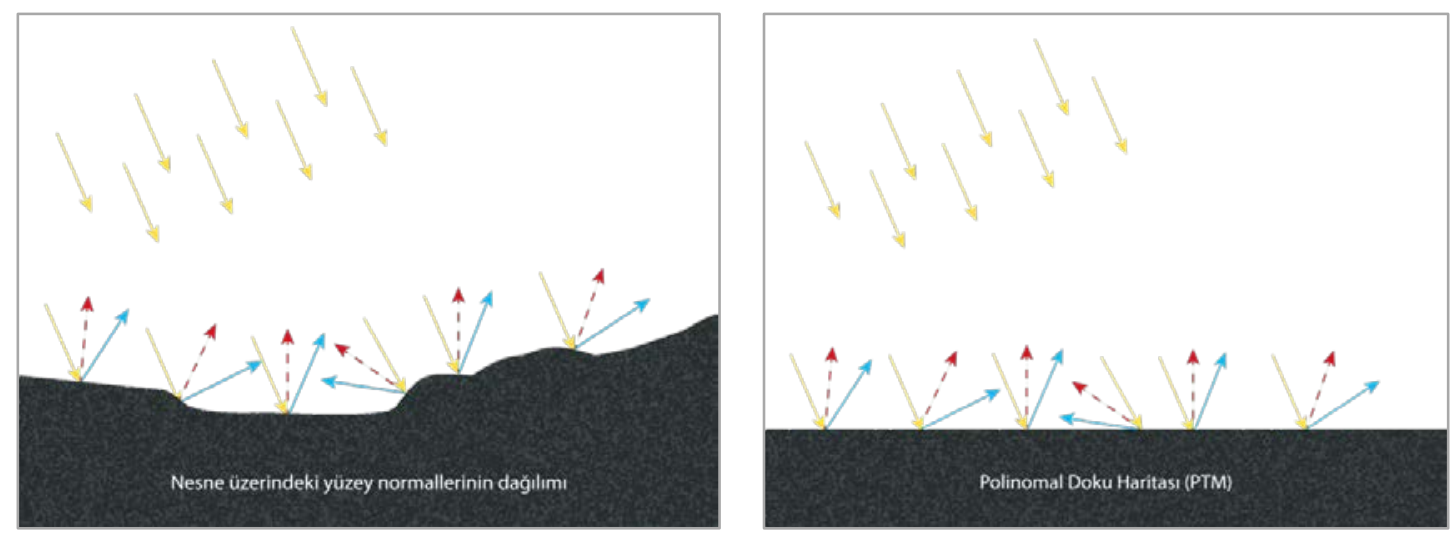

Işı̆ğın düş̧me açısı - - - - -> Yüzey normali

Ișığın yansıma açısı

Fig. 2. PTM dosyası içinde her bir piksele kaydedilen yüzey normalleri

Polinom katsayılarında bulunan söz konusu yüzey normalleri, iki boyutlu PTM görüntüsünde materyalin yüzey topografyasına ait verileri barındırması nedeniyle kültürel miras uygulamaları açısından önem taşımaktadır (Mudge et al. 2005, 29). PTM'ler gerçek 3 boyut verisine sahip 2 boyutlu görüntüler olarak anlaşılabilir.

RTI metodu bir materyal kültür kalıntısı üzerinde ilk kez 2000 yılında epigrafik bir nesneye uygulanmıştır (Malzbender et al. 2000). Araştırmacılar MÖ 2000 yılına ait bir Sümer tabletine PTM görüntülerinden yapılan analiz ile çıplak gözle net bir şekilde görülemeyen metin ve yüzey detaylarını açığa çıkararak RTI metodunun kültürel miras araştırmalarına kazandırılmasında öncü olmuşlardır. 2002 yılında yapılan paleontolojik bir çalışmada ise RTI metodu çeşitli fosiller üzerinde deneyimlenmiş, görüntüleme aşamasında sunduğu düşük renk değerleri ve keskin rölyef hatları, fosillerin analizine pozitif katkı sağlamıştır (Hammer et. al. 2002). 2006 yılında metot, arkeoloji dünyasının en önemli ve eşsiz buluntularından biri olan ve yüz yılı aşkın bir süredir kullanım amacına yönelik bilimsel çalışmalar sürdürülen Antikythera Mekanizması üzerinde uygulanmıştır (Edmunds et al. 2006; Freeth et. al. 2006; Malzbender \& Gelb 2009). Daha önce uygulanan diğer metotlar ile eserde okunabilen karakter sayısı 800 iken, RTI ve X-Ray tomografi kombinasyonu ile yapılan yeni analizler sonucu bu sayı 2000'in üzerine çıkartılarak, mekanizmanın yeni fonksiyonlarına dair önemli ipuçları elde edilmiştir (Earl et al. 2010, 2045).

\section{RTI Kayıt Yöntemleri: Kubbe (Dome) ve Highlight-RTI (H-RTI)}

RTI görüntülerinin algoritmik olarak hesaplanabilmesi için kaydedilen her bir fotoğrafta ışığın hangi yönden geldiği/düştüğü bilinmek zorundadır. Bu görüntü dizisini elde etmek için iki farklı yöntem bulunmaktadır (Mudge et al. 2012, 647). Bu yöntemlerden ilki kubbe formunda bir yarım kürenin tepe noktasına yerleştirilen fotoğraf makinesi ve merkezden eşit uzaklıkta belirli açılarla dağılımı yapılan, konumları 'önceden bilinen' bir 1şık dizisinin bulunduğu 'Dome (Kubbe) Metodu'dur (Malzbender et al. 2001, 524; Willems et al. 2005, 74). Kubbe metodunda objelerin kaydı yapılırken 1 şı ve makine konumları standarttır ve her bir RTI kaydı için farklı 1 şı hesaplamalarına ve fotoğraf makinesi konfigürasyonuna gerek duyulmamaktadır. Bu sayede çekim süresi oldukça düşerek dakikalar içinde -sadece materyali değiştirerek- birçok RTI kaydı yapılabilmektedir (Earl et al. 2010, 2044). Bu avantajlarının yanında kubbe metodunun bazı kısıtlamaları da bulunmaktadır. Örneğin çekimi yapılacak objenin büyük boyutlu olması kubbe için büyük bir sorun teşkil etmektedir. RTI kaydı yapılacak nesnenin ölçüsü, kubbe boyutunun üçte birinden az olmak zorundadır, dolayısıyla kaydı yapılacak nesne boyutları kısıtlıdır (Zanyi et 
al. 2007, 4). Bununla birlikte kubbenin yapım maliyeti oldukça yüksektir ve büyük boyutlarda materyallerin analizi yapılması düşünüldüğünde yüksek bütçeli harcamalar gerektirmektedir (Mudge et al. 2012, 647). Ayrıca arazi uygulamalarında kubbenin alana taşınması ve gerekli güç kaynağının sağlanması gibi kısıtlamalar nedeniyle söz konusu yöntem, iç mekanlarda sikke (Mudge et al. 2005; Palma et al. 2012; Kotoula \& Kyranoudi 2013) ve fosil (Hammer et al. 2002) benzeri küçük boyutlu materyallerin belgelenmesi ve analizi için uygundur.

RTI metodu kubbe sisteminde ortaya çıkan kısıtlamalar ve yüksek maliyetler nedeniyle 2006 yılına kadar kültürel miras araştırmalarında yayılım gösterememiştir. Dünya kültür varlıkları ve sanat eserlerinin, dijital kayıt ve analiz metodolojilerini geliştirmek için çalışmalar yürüten Cultural Heritage Imaging ( $\mathrm{CHI}$ ) ve HP Labs. araştırmacıları tarafindan geliştirilen Highlight-RTI kayıt metodunun tanıtılmasıly Reflectance Transformation Imaging birçok disipline ve araştırmacrya hitap edebilen bir noktaya ulaşmıştır (Mudge et al. 2006).

$H$-RTI, kubbe metoduna göre uygulaması daha esnek bir yöntemdir. Bu yaklaşımda ışık pozisyonlarının kayıt öncesinde hesaplanmasına gerek kalmamakta, 1şık konumları kayıt esnasında yansıtıcı küreler aracılığıyla belirlenmektedir. Böylelikle ışığın nesne üzerine düşüş konumları bilinir kılınmakta ve yüzey normallerinin üç boyutlu nesne topografyasını oluşturması için gerekli RTI (ptm) verileri toplanmaktadır (Mudge et al. 2008, 26). Söz konusu yöntemin en önemli avantajı taşınabilir ekipmanlarla RTI kaydına imkan tanımasıdır. Fotoğraf makinesi, tripod, parlak küreler, harici flaş ve birkaç küçük yardımcı parça ile uygulanabilmekte ve kaydı yapılacak materyal kültür kalıntısının bulunduğu lokasyona taşınabilmektedir (Fig. 3.). Ayrıca bu yöntemle kubbe sistemine göre daha uygun maliyetlerle kayıt ekipmanı oluşturulabilmektedir. $\mathrm{Bu}$ tamamen araştırmacının teçzihat seçimine ve uygulayacağı kültür envanterinin gerektirdiği analiz detayına bağlıdır.

$H$-RTI metodunun kültürel miras araştırmalarına adapte edilmesiyle birlikte RTI kullanımı ivme kazan-

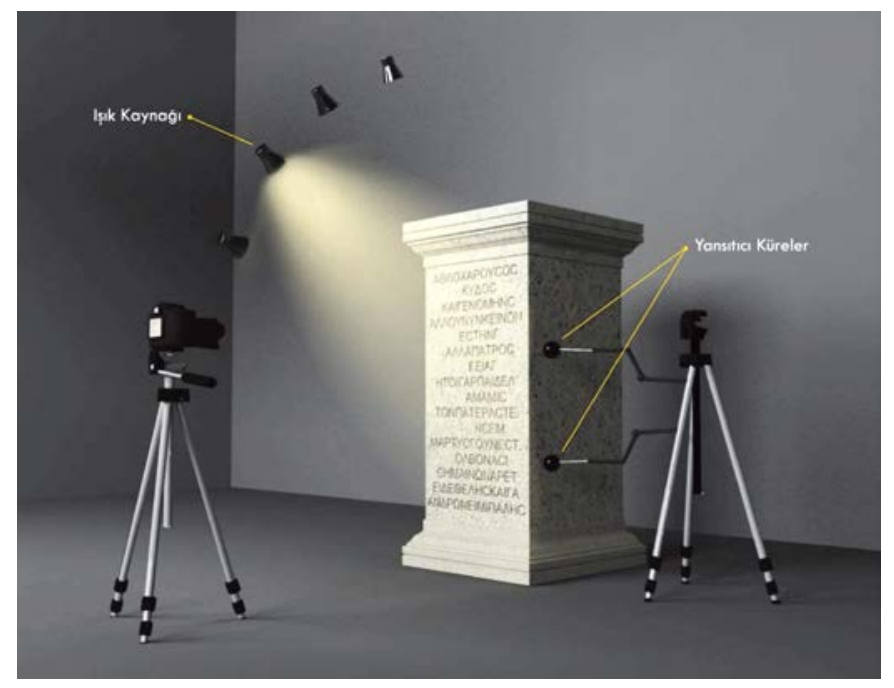

Fig. 3. H-RTI kurulumuna örnek bir senaryo.

(Sahneleme: Ayça Akçay) maya başlamış ve son on yılda metodun yer aldığı proje ve araştırmalar büyük oranda artış göstermiştir. Metodun özellikle; prehistorya (Pitts et al. 2014; Jones et al. 2015), kaya sanat1 (Mudge et al. 2006; Duffy 2010; Mudge et al. 2012), epigrafi (Kleinitz 2012; Kleinitz 2013; Piquette 2014; Tüner-Önen \& Akçay 2014), konservasyon (Earl et al. 2010; Artal-Isbrand et al. 2011; Tamayo et al. 2013), numismatik (Mudge et al. 2005; Diaz-Guardamino \& Wheatley 2013), paleontoloji (Newman 2014) etc. birçok disipline adapte edildiği ve materyallerin belgeleme ve analizine pozitif katkılar sunduğu bilimsel çalışmalarla deneyimlenmiştir. 

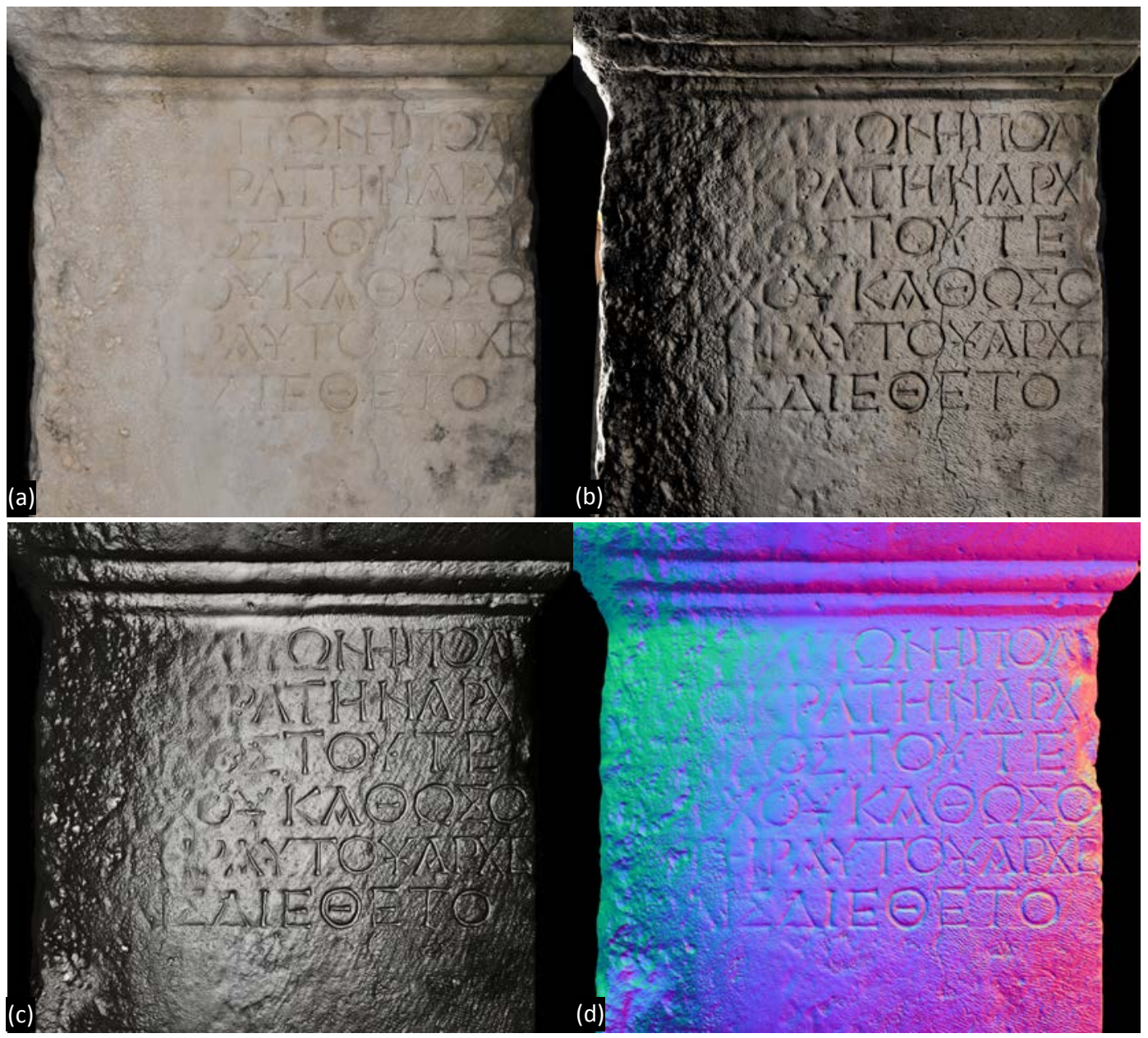

Fig. 4. Tahribata uğramış bir yazıtın RTI görüntüleri. Meydana gelen aşınmalar nedeniyle algılanması güç detayların açığa çıkarılmasında metodun sunduğu görüntüleme filtrelerinin analiz sürecine etkileri: (a) Normal görünüm (b) yaygın kazanç (diffuse gain) (c) yansı katkısı (specular enhancement) (d) yüzey normallerinin dağılımı (Phaselis, Ana Cadde).

\section{H-RTI Görüntülerinin Elde Edilmesi}

RTI görüntülerini elde etmek için izlenmesi gereken üç adım bulunmaktadır; materyalin fotoğraf kaydının yapılması, kaydedilen görüntü verilerinin işlenmesi ve oluşturulan matematiksel modelin görüntülenmesidir. RTI görüntüleri bir nesnenin, değişen ve bilinen aydınlatma açıları altında sistematik olarak bir dizi (24-60) fotoğrafinın kaydedilmesiyle sağlanmaktadır. Sabitlenen bir fotoğraf makinesiyle çekilen her bir karede belirli yön ve açılardan uygulanan 1şık kaynağı (flaş/sürekli 1şık) ile nesne yüzeyi aydınlatılarak fotoğraf kaydı yapılmaktadır. Kurulum esnasında nesnenin etrafına iki adet siyah/kırmızı renkte parlak küre yerleştirilmektedir. Işığın geldiği yönü ve nesne yüzeyindeki yansıtma değerleri kayıt sonrasında RTI Builder yazılımıyla sentezlenerek bu küreler üzerinden hesaplanmaktadır. Kayıt boyunca eserin çevresinde yarım küre şeklinde 1şık-nesne mesafesinin sabit kalması şartıyla - bir ışık dağılımı sağlanmalıdır (Earl et al. 2010). Bu eşit dağılım, nesne yüzeyinin çevresi on iki saat dilimine bölünerek ve her bir dilimde 1ş1k 1565 derece aralıklarında üç veya dört farklı açıdan nesne yüzeyine uygulanarak elde edilebilmektedir. Bu süreç sonunda yarımküre biçiminde eşit olarak dağılımı gerçekleşen bir ışık dizisi elde edilmektedir (Fig. 5-6). 


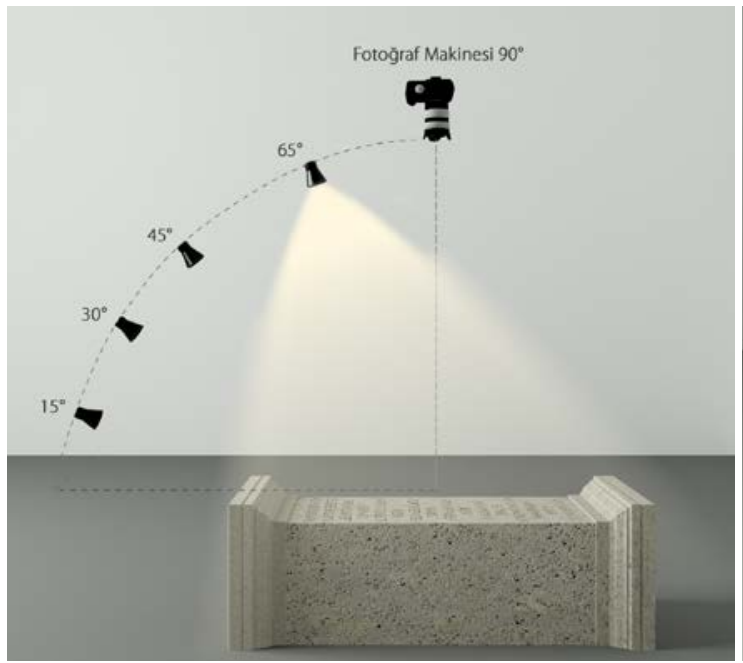

Fig. 5. Dikey çekim H-RTI kaydında yüzeye uygulanan 1şık açıları. (Sahneleme: Ayça Akçay)

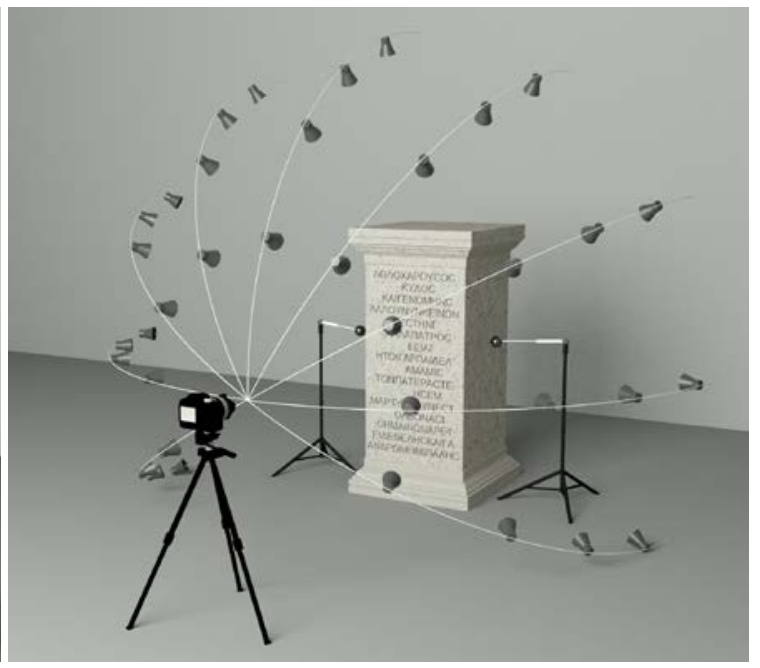

Fig. 6. Yatay çekim H-RTI kaydı sırasında yazıt etrafinda oluşturulan yarım küre formunda ışık dağılımı.

Işığın nesneye olan uzaklığını hesaplamak için materyalin diyagonal uzunluğunun üç veya dört katı baz alınmaktadır. Kayıt süresince fotoğraf makinesinin ve kürelerin sabit olarak kalması önemlidir. Zira görüntülerdeki yüzey normalleri hesaplanırken piksel bazlı sentezleme yapılmakta ve görüntüler arasında en ufak bir piksel kayması, hatalı yansıtma hesaplamalarına sebep olarak; bulanık, gerçeğiyle örtüşmeyen ve analizi mümkün olmayan bir dijital kopyanın ortaya çıkmasına sebep olmaktadır (Mudge et al. 2006, 198). Bunun yanında başarılı bir RTI kaydı için ön hazırlık ve planlamanın rolü oldukça önemlidir. Özellikle arazi şartlarında kaydı yapılacak materyal kültür kalıntısı etrafındaki ağaç, kaya, engebeli zemin etc. benzeri engel teşkil edebilecek nesneler göz önünde bulundurulmalı ve kurulum bu şartlar dikkate alınarak yapılmalıdır (Fig. 78). Dış mekanda gün 1şı̆̆ının yoğun olduğu durumlarda -materyal yüzeyinin tamamen gölgede kalması koşuluyla- kuvvetli bir harici 1şı1k kaynağı ve lens üzerinde doğal yoğunluk filtresi (ND) kullanılarak RTI kaydı yapılabilmektedir (Barbosa 2009, 34; Gabov-Bevan 2011, 8).

Materyal yüzeyine uygulanan ışığın yarım küre formunda iyi bir dağılımının yapılması sonuca etki eden önemli faktörlerdendir (Dellepiane et al. 2006, 184). Iş̧k dağılımının iyi bir şekilde yapılması daha net ve tutarlı sonuçlar alınmasına fayda sağlayacaktır. Bununla birlikte, kayıt sırasında belirlenen nesne-ışı mesafesinin standart kalması ve fotoğraf ekipmanının kalitesi gibi etmenler yüksek kalitede bir rti/ptm dosyası elde etmek için önem teşkil etmektedir. Buna bir örnek vermek gerekirse; 20 megapiksel çözünürlüğe sahip bir RTI görüntüsünde, nesnenin yüksek detaylı bir yüzey formuna karşılık gelen 20 milyon kodlanmış yüzey normali (vektör) bulunmaktadır (Mudge et al. 2012, 648).

Kaydı yapılan materyalin $R T I$ görüntüsünü oluşturmak için $C H I$ tarafından açık kaynak kodlu ve ücretsiz olarak sunulan RTI Builder (detaylı bilgi için bk. http://culturalheritageimaging.org) programı kullanılmaktadır (Cultural Heritage Imaging 2013a). Elde edilen görüntü verileri RTI Builder programında sentezlenerek, nesne yüzeyinin yapı haritası otomatik olarak oluşturulmaktadır. Bu aşamada, her bir fotoğraf işlenerek 1şığın geliş yönü belirlenmekte, ardından normallerin hesaplanabilmesi için gerekli olan ışık seviyeleri ölçülmekte ve yansıtma özelliklerinden nesnenin yüzey topografyası elde edilerek RTI dosyası oluşturulmaktadır (Barbosa 2009, 58). 


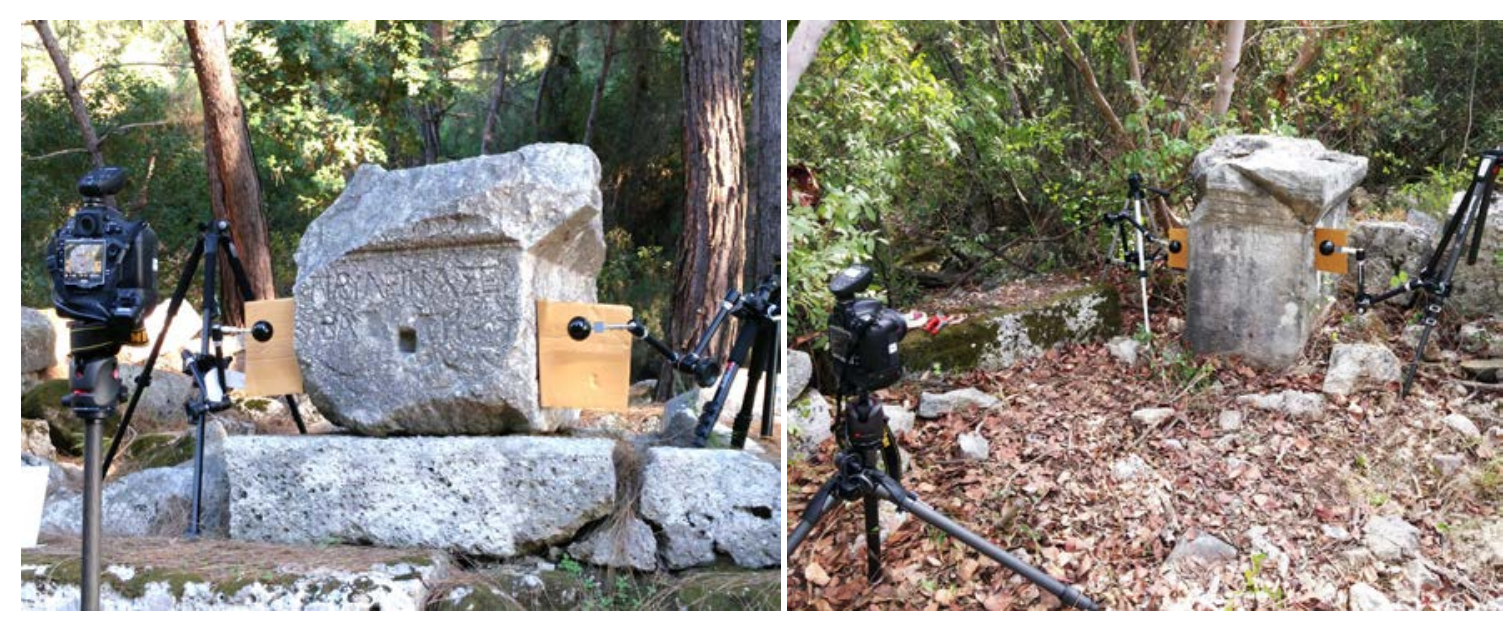

Fig. 7-8. Arazi koşullarında yazıtların $H-R T I$ kaydı aşamasından bir görünüm (Phaselis, Güney Liman \& Akropolis )

\section{Epigrafik Belgelerin RTI Metodu ile Görüntülenmesi}

RTI metodu, kültürel miras araştırmalarında özellikle ışığın, nesne yüzeyinin geometrisi ile etkileşimli olduğu durumlarda kullanıldığında, materyalin görsel analizinde oldukça etkilidir. Materyalin yansıtma özellikleri ve yüzey dokusu gibi karakteristik özellikleri, analiz sürecine dair önemli algısal ve bilişsel ipuçları sunmaktadır. RTI modeli üzerindeki interaktif analizi geliştirmek için, yüzey detaylarının algısını artırabilmek amacıyla çeşitli algoritmik filtreleme teknikleri geliştirilmiştir. Eserlerin normal fotoğrafları üzerinde yüzey algısının artırılabilmesi için, bilinen fotoğraf görüntüleme ve düzenleme programlarının kullanımına gidilebilir. Bu programlar üzerinde histogram eşitlemesi, keskinlik ve karşıtlık ayarlarını artırma gibi yöntemler bazı durumlarda görsel algı düzeyini artırmada işe yarayabilmektedir. Fakat bu tür yaklaşımlar iki boyutlu (2D) fotoğraflara bağlı kalarak uygulandığ 1 için istenilen sonucu elde etmek genellikle mümkün olmamaktadır (Malzbender et al. 2006, 1).

RTI dosyalarının görüntülendiği RTI Viewer (Cultural Heritage Imaging 2013b) programı, kaydı yapılan nesnenin 'sanal kopyası' üzerinde çok yönlü analiz yürütmeye imkan verebilmektedir (Fig. 9). Söz konusu programda eserin yüzeyine istenilen açıdan interaktif olarak yapay 1şık uygulanarak materyal kültür kalıntısına ait karanlıkta kalan birçok nokta aydınlatılmaktadır. Görüntüleyicinin analiz sürecine etki eden en önemli fonksiyonu ise yansitma değerlerinin kodlandığı yüzey topografyasına algoritmik görüntüleme filtreleri uygulanabil-

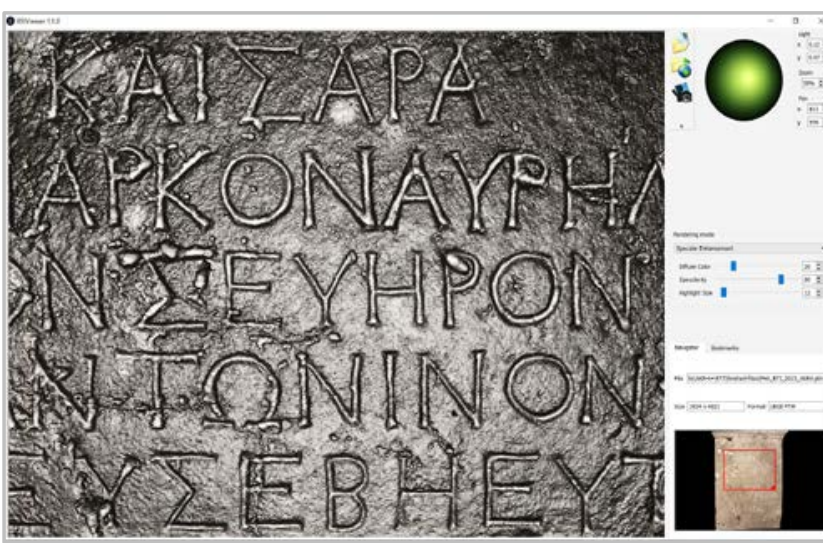

Fig. 9. RTI Viewer programından analiz süreci: Yans1 katkısı kullanılarak renk değerleri kaldırılmakta ve sadece yazııın yüzey dokusu ortaya çıkmaktadır. mesidir. Bu filtreler kullanılarak eserlerin yüzey detaylarına ait çok yönlü analiz süreci yürütülmekte ve geleneksel fotoğraflama metotlarıyla veya direkt analizle (çıplak gözle) görülemeyen detaylar görünür k1lınmaktadır (Schroer 2012, 38; Barbosa 2009, 77; Tamayo et al. 2013, 540; Lehoux 2013, 114; Diaz \& Wheatley 2013, 194). 


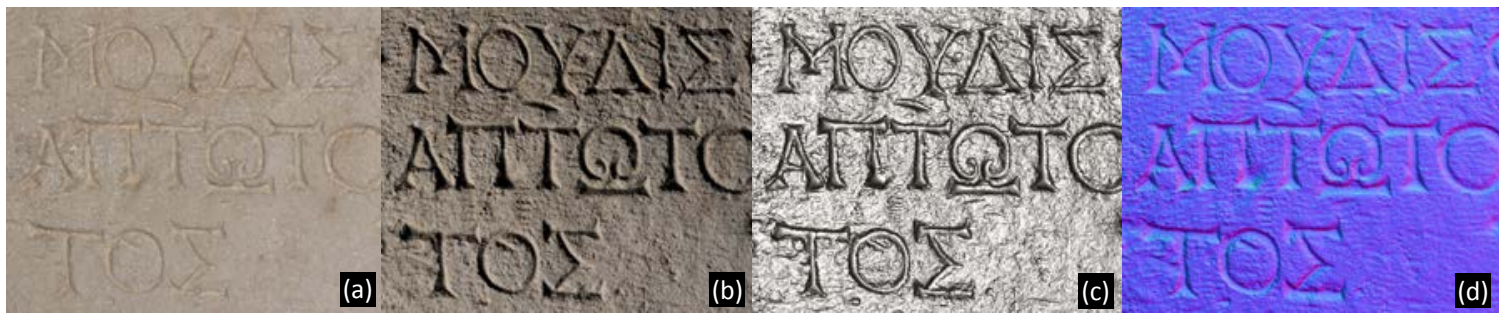

Fig. 10. RTI Viewer’da bulunan görüntüleme fitrelerinin yazıtların analiz aşamasına sunduğu katkılar.

\section{Yazıtların Yüzey Analizinde Kullanılan Görüntüleme Filtreleri}

RTI Viewer'da nesnenin yüzey normallerine ve renk değerlerine çeşitli matematiksel dönüşüm filtreleri uygulanarak güçlükle algılanabilen yüzey detayları ortaya çıkarılabilmektedir. Bu filtreler nesnenin yüzey şeklinden ve/veya renk değerlerinden elde edilen verilere, belirli algoritmaların uygulanmasıyla oluşturulmaktadır. Arkeolojik ve epigrafik materyallerin incelenmesinde özellikle yaygın kazanç (diffuse gain) ve yansı katkısı (specular enhancement) analize katkı sağlayan en etkili görüntüleme filtreleridir.

Yaygın kazanç, RTI görüntüsünde birbirine bitişik pikseller arasındaki karşıtlık değerini artırarak yüzeydeki rölyef ve insizyon yoğunluğunu belirgin k1lmak için kullanılan bir filtredir. Diğer bir deyişle, nesnenin yüzeyinde ani değişiklik gösteren yükseklik ve derinliklerin bulunduğu normallerin değerlerini artırarak, dokusal morfoloji algısını iyileştirmektedir (Fig. 10b-12b). Bu özellikleri sayesinde yazıtların harf karakterizasyonunda oldukça etkili sonuçlar vermektedir. Yaygın kazanç kullanılırken piksellerin renk değişimine uğraması nedeniyle renk analizlerinde kullanılması önerilmemektedir (Cultural Heritage Imaging 2013, 14).

Yans1 katkıs1, nesnenin yansıtma fonksiyonlarına, yapay yansı katkıları uygulayarak yüzeydeki algıyı belirgin bir şekilde artırmaktadır (Earl et al. 2010, 3). Bu filtre, nesne rengini ve yüzey topografyasından üretilen yansışmaları birbirinden bağımsız parametreler kullanarak görüntülemeye olanak sağlamaktadır (Cultural Heritage Imaging 2013, 14). Yans1 katkısı kullanılarak, materyal yüzeyindeki renk değerlerinin kaldırılmasıyla yazıtların dokusu tamamen ortaya çıkmakta ve detaylı bir analize imkan sunmaktadır. Böylelikle, nesnenin yansıtma değerlerinin artırılmasıyla mat görünen yazıt yüzeyine, metal bir levhaya işlenmiş gibi 'parlak' bir yüzey kazandırılması ile önceden görülmesi mümkün olmayan detaylar bu süreçte ortaya çıkarılabilmektedir (Fig. 10c).

RTI görüntülerinde yüzey normalleri de görüntülenebilmektedir. Normaller sayısal modellerde nesnelerin yüzey şekillerini betimlemekte, ışığın düştüğü noktadan nasıl yansıması gerektiğini hesaplamak için yüzeyin yansıtma özelliklerini belirlemede kullanılmaktadır (Zanyi et al. 2007, 22). RTI Viewer'da yüzey normalleri (surface normals) seçeneği ile yüzey detayları $R G B$ renk kanalları aracılığıyla (genellikle mavi-kırmızı tonlarda) vektörlerin düzlemdeki dağılım yönünü gösteren bir görüntü sunmaktadır (Fig 10d-11d). Yüzey normalleri seçeneğiyle, kaydı yapılan nesnelerin RTI görüntülerinin kalitesine dair gözlemlerin yanı sıra yazıtların farklı zaman dilimlerinde yapılan RTI kayıtları üzerinden tahribat analizi yapılabilmektedir.

Bahsedilen bu filtrelere ek olarak, RTI Viewer programımda bulunan luminans ve keskinlik maskeleri, çoklu 1şık görünümleri gibi çeşitli görüntüleme seçenekleri, görsel algıyı arttırarak materyal kültür kalıntılarının analiz süreçlerine pozitif katkılar sunmaktadır. 


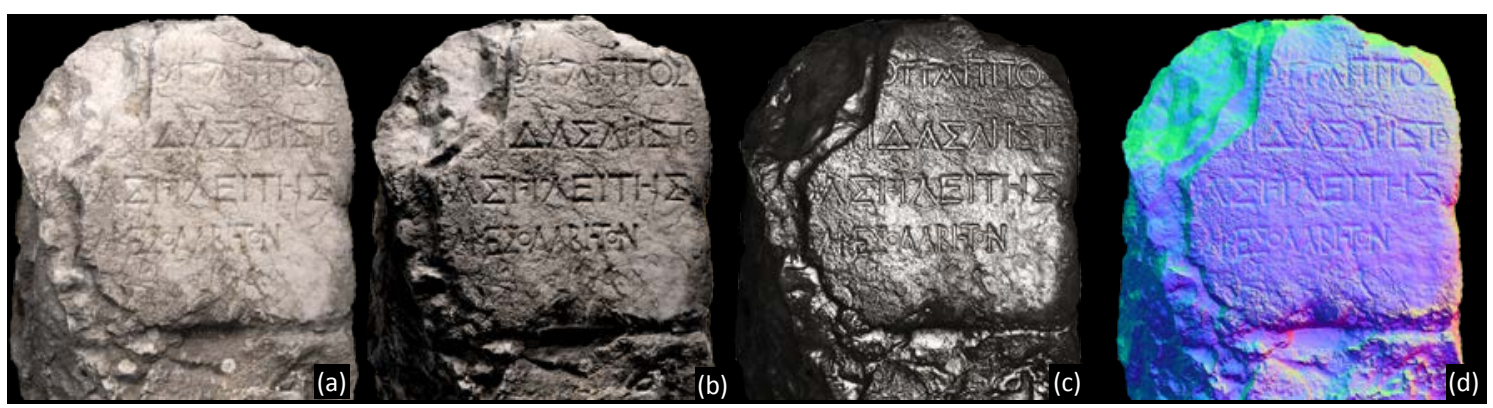

Fig. 11. Yazıt bloğu üzerinde RTI görüntü filtrelerinin geçişleri. (b) Yaygın Kazanç (Diffuse Gain) ve (c)Yansı Katkısı (Specular Enchancement) görsel algıyı güçlendirerek yazıtların deşifrasyonuna önemli derecede pozitif katkı sağlamaktadır (Phaselis, Büyük Hamam)

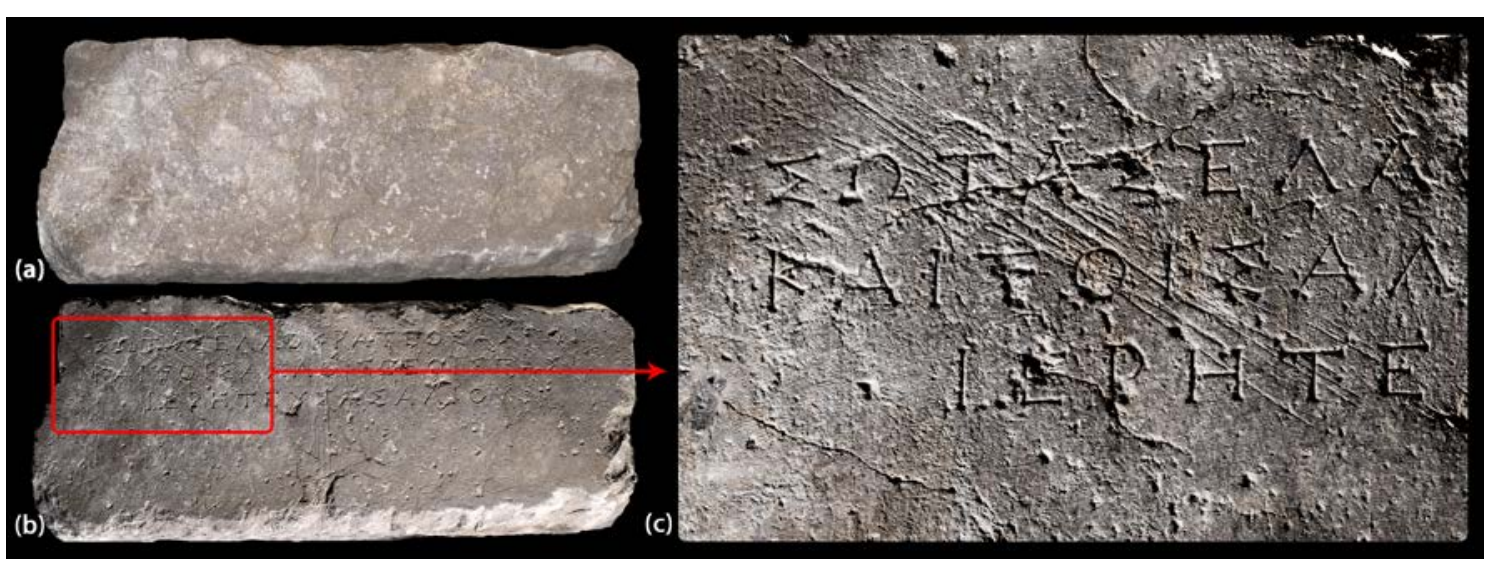

Fig. 12. Yüzeyinde deformasyon meydana gelen bir yazıtın analiz detayı. Meydana gelen aşınmalar nedeniyle harf karakterlerinde meydana gelen yıpranmaların görüntüleme filtreleri kullanılarak incelenmesi: (a) normal görünüm (b) yaygın kazanç (diffuse gain) (c) \%58 oranında yakınlaştırılmış yaygın kazanç detayı. (Phaselis, Büyük Hamam).

\section{Tartışma: Metodun Avantajları ve Kısıtlamalarına Dair Gözlemler}

$R T I$ tahribatsız ve temassız bir kayıt yöntemidir. Eserlerin yüzey detayları fotoğraflama yoluyla elde edildiği için materyal kültür kalıntısı ile temasa ihtiyaç duyulmamaktadır. Yazıtların kopyalanmasında kullanılan estampaj/lateks uygulamalarının korunma durumu kritik olan yazıtlara verebileceği zarar göz önünde bulundurulduğunda, yazıtların tahribatsız olarak belgelenmesi ve analizi için RTI metodu önemli bir noktada durmaktadır. RTI metodu iki boyutlu bir kayıt yöntemi olmasına rağmen, yüzey normallerinin sağladığı yansıtma değerleri üç boyutlu yüzey görüntüleri sunmaktadır. Her bir pikselde renk verilerinin barındırmasının yanı sıra yüzey normallerini de kaydederek sunduğu makro-topografik veriler ile konvansiyonel fotoğraf teknikleriyle veya doğrudan analizle görülemeyen detayları görünür kılabilmektedir. Ayrıca RTI mikroskopla veya çeşitli filtreler kullanılarak Ultraviolet-RTI ve Infrared-RTI gibi farklı görüntüleme yöntemleriyle uyum sağlayabilmektedir. Metot diğer teknolojik belgeleme yöntemleriyle kıyaslandığında çok daha düşük maliyetlerle elde edilebilmektedir. Metodun uygulanacağı kültür envanterinin gerektirdiği analiz detayına bağlı olarak istenilen düzeyde fotoğraf ekipmanlarıyla RTI kaydı yapılabilmektedir. Çalışma kapsamında bir yazıt yüzeyi üzerinde farklı fotoğraf makineleriyle deneyimlediğimiz testler karşılaştırıldığında orta seviyede bir fotoğraf makinesi ile de analiz için tatmin edici sonuçlar elde ediliği gözlemlenmişir (Fig 13). RTI metodu nesnelerin yüzey bilgilerini açığa çıkarmaktadır. Yüzeyi harç veya sıva gibi malzemelerle kaplanan veya çok fazla tahrip olan yazıtlarda gerekli rölyef ya da insizyonlar mevcut 
değilse metodun analiz imkanı sağlaması mümkün değildir. Metot yüzey bazlı veri kaydı yaptığı için $X$-Ray teknolojilerinde görülebilen alt katmanların analizini gerçekleştirememektedir. RTI metoduyla karşılaştırılan bir diğer belgeleme ve görüntüleme yöntemi olan 3B lazer tarama teknolojisi de hassas ve etkili sonuçlar verebilmektedir. Fakat bu teknolojiyi uygulayabilmek için oldukça yüksek bütçelere ihtiyaç duyulmaktadır. RTI dosyalarının oluşturulması ve görüntülenmesi için, fotogrametri ve lazer tarama yöntemlerinin gerektirdiği yüksek donanımlı bilgisayarlara ihtiyaç duyulmamaktadır. Söz konusu metot, materyallerin detaylı analizine imkan sunmasına rağmen metrik veriler sağlayamamaktadır. Eğer üç boyut ortamında kesin ölçüm verileri elde edilmek isteniyorsa lazer tarama veya fotogrametri metotları uygulanmalıdır. Ayrıca RTI metodu sadece nesnelerin yüzey bilgilerini sayısallaştırmaktadır. 3B lazer tarama veya fotogrametri gibi nesnenin üç boyutlu modelini oluşturmamaktadır. Büyük ölçekli eserlerin RTI kaydını gerçekleştirebilmek için en az iki kişiye ihtiyaç duyulmaktadır. Bir kişi ışığı tutarken diğer kişi nesnekamera mesafenin sabit kalmasını sağlayarak kamerayı tetiklemektedir. Bazı durumlarda gerekli diyagonal mesafenin sağlanması esnasında arazide bulunan yapı, ağaç, bitki gibi engellerle karşılaşılabilmektedir. Bu engellere ek olarak çoğu yazıt bloğunun zemin seviyesinde bulunması sebebiyle yarım küre şeklinde bir çekim gerçekleştirmek mümkün olmamaktadır. Bu durumda yüzeye uygulanan 1 şı dağılımı ne kadar fazla olursa sonucun da bir o kadar iyi olacağı unutulmamalidır.

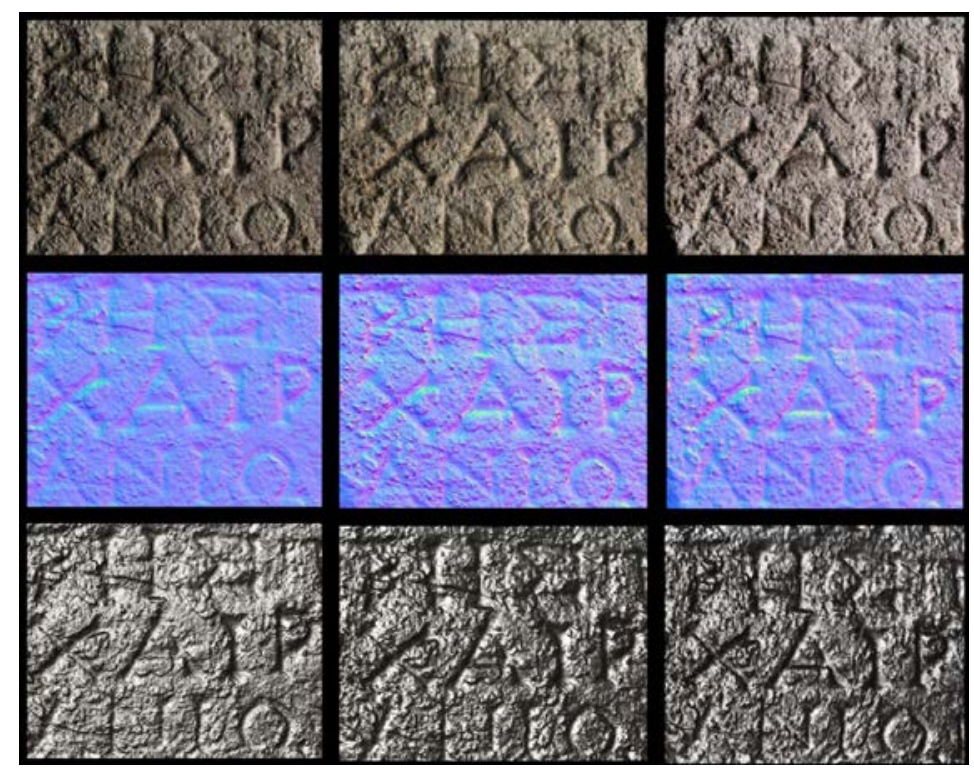

Fig. 13. Farklı fotoğraf makineleriyle elde edilen $R T I$ sonuçlarının karşılaştırılması. (Solda) Nikon'un üst seviye modellerinden D800 (36.3 mp) ile elde edilen detaylara bakıldığında yüzey topografyasını oluşturan normal vektörleri diğer sonuçlara göre daha hassas dağ1$11 \mathrm{~m}$ göstermektedir. (Ortada) Orta seviye bir model olan D5300 (24.2 mp) ile elde edilen sonuç, analiz için yeterli detay sunmaktadır. (Sağda) 2006 yılında üretilen D80 (10.2 mp) modeli ile elde edilen RTI kayd 1 analiz için yeterli sonuçlar verebilmektedir (Phaselis).

\section{Değerlendirme ve Sonuç}

RTI metodu özellikle son 10 yılda kültürel miras araştırmalarının bir çok alanında belgeleme ve analiz süreçlerinde yardımcı bir metot olarak kullanım görmeye başlamıştır. Özellikle yurtdışı merkezli üniversite/enstitü projelerinde; arkeoloji, epigrafi, prehistorya, konservasyon, numismatik gibi birçok disiplinde ve müzelerde bulunan eserlerin, dijital arşivlerinin oluşturulmasında yürütülen çalışmalarda RTI metodu başarılı bir şekilde uygulanmaktadır. Söz konusu metot, araştırmaların daha hassas ve güvenilir bir biçimde yürütülmesine olanak sağladığı gibi, elde edilen bilimsel verilerin ve sonuçların değerlendirilmesine de büyük kolaylıklar sağlamaktadır.

$R T I$, eserlerin yüzey analizlerinde yüksek maliyetli ekipmana gereksinim duyan, uygulama süresi daha fazla ve yüksek boyutlu geometrik verilerin getirdiği uzun işleme süreleri gerektiren lazer teknolojisine alternatif pratik bir metot olarak kullanılabilir. Müzelerde, antik kentlerde 
veya kent teritoryumlarında bulunan gerek küçük buluntular gerekse büyük boyutlardaki taşınmaz kültür varlıklarının, metot yardımıyla doğru ve hassas bir şekilde dökümantasyonu yapılabilir ve elde edilen sayısal veriler ışı̆̆ında araştırmacılar ofislerinde kaydı yapılan nesnelere dair detaylı analiz çalışmaları yürütebilirler.

Epigrafi çalışmalarında RTI metodunun taşınabilir ekipmanlarla uzak lokasyonlarda kayıt yapmaya imkan vermesi ve düşük maliyetlerle uygulanabilir bir metot olmasının yanı sıra korunma durumu hassas yazıtlar için tahribatsız belgelemeye imkan sunması önemli bir noktada durmaktadır. Yazıtların deşifrasyon süreçlerinde RTI metodunun gelişmiş görüntüleme özellikleri kullanılarak; yüzeydeki karakterler istenilen açıdan interaktif olarak aydınlatılabilmekte, makro veya mikro ölçeklerde detaylı analizleri yapılabilmekedir. Algoritmik sahneleme fonksiyonları uygulanarak görsel algının güçlendirilmesiyle direkt analizle görülemeyen yüzey detayları görünür kılınabilmekte ve harf karakterizasyonuna pozitif katk1 sağlamaktadır. Bununla birlikte her geçen gün doğal/beşeri sebeplerden dolayı tahrip olan epigrafik belgelerin bir an önce teknolojinin bizlere sunduğu yeni metodolojiler 1şığında belgelenerek 'dijital koruma' altına alınması ve 'gerçek temsilleri’nin sanal kopyaları oluşturularak kültür mirasımızın gelecek nesillere aktarılması açısından önem arz etmektedir.

$R T I$ geniş bir araştırmacı kitlesine hitap etmesine rağmen henüz fazla yayılım gösterememiştir. Daha fazla araştırmacıya ulaşabilmesi için yurt dışı merkezli enstitü ve üniversitelerde metodun kullanımına dair çalıştaylar düzenlenmekte ve ilgili yayınlar hazırlanmaktadır. RTI kullanımının, ülkemizde yürütülen kültürel miras araştırmalarına özellikle de antikiteye dair önemli bilgiler sunan epigrafi çalışmalarına kazandırılması, yazıtların analiz süreçleri sırasında karşılaşılan zorlukları ortadan kaldırmak ve kültür mirasımızın sayısallaştırılarak belgelenmesi ve korunması için oldukça önemlidir. Bu bağlamda ülkemizde yürütülen epigrafi çalışmalarında kullanılan geleneksel metotlarla çağımızın getirdiği yeni teknolojik yöntemlerin harmanlanması, Anadolu epigrafi çalışmaları için pozitif katkılar sağlayacaktır. 


\section{KAYNAKÇA}

Artal-Isbrand P., Klausmeyer P., Murray W. (2011). “An Evaluation of Decorative Techniques on a RedFigure Attic Vase from the Worcester Art Museum using Reflectance Transformation Imaging (RTI) and Confocal Microscopy with a Special Focus on the 'Relief Line’”. Eds. P. Vandiver, W. Li, J. L. Ruvalcaba Sil, C.L. Reedy \& L.D. Frame. Materials Issues in Art and Archaeology IX/1319 (2011) 3-33. Doi: http://dx.doi.org/ 10.1557/opl.2011.793

Barbosa J. C. G C. (2009). RTI-Based Techniques and Tools for Digital Surrogates. Master Thesis. Universidade do Minho, Portugal 2009.

Cultural Heritage Imaging (2013a). RTI Builder Guideline Verison 2.0.2. http://culturalheritageimaging.org/ What_We_Offer/Downloads/Process/index.html Erişim Tarihi: 28.06.2016.

Cultural Heritage Imaging (2013b). RTI Viewer Guideline Version 1.1. http://culturalheritageimaging.org/ What_We_Offer/Downloads/View/index.html Erişim Tarihi: 28.06.2016.

Dellepiane M., Corsini M., Callieri M. \& Scopigno R. (2006). "High Quality PTM Acquisition: Reflection Transformation Imaging for Large Objects". The $7^{\text {th }}$ International Symposium on Virtual Reality, Archaeology and Cultural Heritage (VAST'06), Eurographics Association, Nicosia, Cyprus (2006) 179-186.

Diaz-Guardamino M. \& Wheatley D. (2013). "Rock Art and Digital Technologies: The Application of Reflectance Transformation Imaging (RTI) and 3D Laser Scanning to the Study of Late Bronze Age Iberian Stelae”. MENGA: Journal of Andalusian Prehistory 4 (2013) 187-203.

Duffy S. M. (2010) "Polynomial Texture Mapping at Roughting Linn Rock Art Site". ISPRS Technical Commission V Mid-Term Symposium 38/5. Newcastle, UK (2010) 213-217.

Edmunds M. G., Freeth A., Bitsakis Y., Moussas X., Seiradakis J., Magkou E., Zafeiropoulou M., Haycock P., Hadland P., Ramsay A. Gelb D \& Malzbender T. (2006). "The Antikythera Mechanism Real Progress Through Greek/UK/US Research”. Ed. N. H. Solomos, The $7^{\text {th }}$ International Conference of the Hellenic Astronomical Society 848 (2006) 913-918.

Earl G., Martinez K. \& Malzbender T. (2010). "Archaeological Applications of Polynomial Texture Mapping: Analysis, Conservation and Representation”. Journal of Archaeological Science 37/8 (2010) 2040-2050. Doi: 10.1016/j.jas.2010.03.009

Freeth T., Bitsakis Y., Moussas X., Seiradakis J. H., Tselikas A., Mangou H., Zafeiropoulou M., Hadland R., Bate D., Ramsey A., Allen M., A. Crawley., Hockley P., Malzbender T., Gelb D., Ambrisco W. \& Edmunds M. G. (2006). "Decoding the Ancient Greek Astronomical Calculator Known as the Antikythera Mechanism”. Nature 444 (2006) 587-591. Doi:10.1038/nature05357

Gabov A. \& Bevan G (2011) "Recording the Weathering of Outdoor Stone Monuments Using Reflectance Transformation Imaging (RTI): The Case of the Guild of All Arts (Scarborough, Ontario)". Journal of the Canadian Association for Conservation 36 (2011) 3-14.

Hammer O., Bengston S., Malzbender T., Gelb D. (2002) "Imaging Fossils Using Reflectance Transformation and Interactive Manipulation of Virtual Light Sources". Paleontologia Electronica 5/1 (2002). http://palaeo-electronica.org/2002_1/fossils/issue1_02.htm

Jones A. M., Cochrane A., Carter C., Dawson I., Díaz-Guardamino M., Kotoula E. \& Minkin L. (2015). "Digital Imaging and Prehistoric Imagery: A New Analysis of the Folkton Drums". Antiquity 89 (2015) 1083-1095. Doi:10.15184/aqy.2015.127.

Keppie L. (1983). Understanding Roman Inscriptions. Baltimore, USA 1991.

Kleinitz C. (2012). "Reflectance Transformation Imaging (RTI) in der Bestandsdokumentation der Sekundärbilder und -inschriften von Musawwarat es Sufra im Rahmen des Musawwarat Graffiti Project”. Der Antike Sudan. Mitteilungen der Sudanarchäologischen Gesellschaft zu Berlin 23 (2012) 7-20.

Kleinitz C. (2013). "Die Sekundärbilder und -inschriften der Großen Anlage von Musawwarat es Sufra und das Musawwarat Graffiti Project”. Ed. St. Wenig \& K. Zibelius-Chen, Die Kulturen Nubiens ein afrikanisches Vermächtnis. Dettelbach, Deutschland (2013) 399-413. 
Kotoula E \& Kyranoudi M. (2013). "Study of Ancient Greek and Roman Coins Using Reflectance Transformation Imaging”. E-Conservation 25 (2013) 74-88.

Lehoux D. (2013). “Ancient Science in a Digital Age”. Isis 104 (2013) 111-118. Doi: 10.1086/669892

Malzbender T., Gelb D., Wolters H. \& Zuckerman B. (2000). "Enhancement of Shape Perception by Surface Reflectance Transformation”. Technical Report, Hewlett-Packard Laboratories 2000.

Malzbender T., Gelb D. \& Wolters H. (2001). "Polynomial Texture Maps". $28^{\text {th }}$ Annual Conference on Computer Graphics and Interactive Techniques (SIGGRAPH'01). New York, USA (2001) 519-528. Doi: $10.1145 / 383259.383320$

Malzbender T., Wiburn B., Gelb D. \& Ambrisco B. (2006). "Surface Enhancement Using Real-Time Photometric Stereo and Reflectance Transformation”. 17 ${ }^{\text {th }}$ Eurographics conference on Rendering Techniques (EGSR '06). Nicosia, Cyprus (2006) 245-250. Doi: 10.2312/EGWR/EGSR06/245-250

Malzbender T., Gelb D. (2009). Interactive Relighting of the Antikythera Mechanism. Source: http://www.hpl.hp.com/research/ptm/antikythera_mechanism/ Erişim Tarihi: 14.06.2016.

McLean B. H. (2002). An Introduction to Greek Epigraphy of the Hellenistic and Roman Periods from Alexander the Great Down to the Reign of Constantine (323 B.C.-A.D. 337). Michigan, USA 2002.

Mudge M., Voutaz J. P., Schroer C. \& Lum M. (2005). "Reflection Transformation Imaging and Virtual Representations of Coins from the Hospice of the Grand St. Bernard”. The $6^{\text {th }}$ International Symposium on Virtual Reality, Archaeology and Cultural Heritage (VAST'05) (2005) 29-39. Pisa, Italy.

Mudge M., Malzbender T., Schroer C. \& Marlin L. (2006). "New Reflection Transformation Imaging Methods for Rock Art and Multiple-Viewpoint Display”. Eds. M. Ioannides, D. Arnold, F. Niccolucci \& K. Mania, The $7^{\text {th }}$ International Symposium on Virtual Reality, Archaeology and Cultural Heritage (VAST’06), Eurographics Association, Nicosia, Cyprus (2006) 195-202.

Mudge M., Malzbender T., Chalmers A., Scopigno R., Davis J., Wang O., Gunawardane P., Ashley M., Doerr M., A Proenca. \& Barbosa J. (2008). "Image-Based Empirical Information Acquisition, Scientific Reliability, and Long-Term Digital Preservation for the Natural Sciences and Cultural Heritage”. Eds. M. Roussou \& J. Leigh, Eurographics (2008) . Crete, Greece.

Doi: 10.2312/egt.20081050

Mudge M., Schroer C., Noble T., Matthews N., Rusinkiewicz S. \& Toler-Franklin C. (2012). "Robust and Scientifically Reliable Rock Art Documentation from Digital Photographs”. Eds. J. McDonald \& P. Veth. A Companion to Rock Art. (2012) 644-659. Chichester, UK. Doi: 10.1002/9781118253892.ch36

Newman S. E. (2014). “Applications of Reflectance Transformation Imaging (RTI) to the Study of Bone Surface Modifications”. Journal of Archaeological Science 53 (2014) 536-549.

Doi: 10.1016/j.jas.2014.11.019

Palma G., Siotto E., Proesmans M., Baldassari M., Baracchini C., Batino S., \& R. Scopigno (2012). “Telling The Story of Ancient Coins By Means Of Interactive RTI Images Visualization”. The 40 Computer Applications and Quantitative Methods in Archaeology (CAA2012) (2012) 26-30. Southampton, UK.

Piquette K. E. (2014). “Scribal Practice and an Early Dynastic Stone Vessel Inscription. Material and Aesthetic Implications”. Eds. A. Dodson, J. Johnston \& W. Monkhouse, A Good Scribe and an Exceedingly Wise Man. Studies in Honour of W.J. Tait (2014) 241-250. London.

Pitts M., Miles J., Pagi H \& Earl G. (2014). "HOA HAKANANAI'A: A New Study of an Easter Island Statue in the British Museum”. The Antiquaries Journal 94 (2014) 291-321. Doi: 10.1017/ S0003581514000201

Schroer C. (2012). “Advanced Imaging Tools for Museum and Library Conservation Research”. Bulletin of the American Society for Information Science and Technology 38/3 (Marzo, 2012) 38-42.

Tamayo S. N. M., Andres J. V. \& Pons J. O. (2013). “Applications of Reflectance Transformation Imaging for Documentation and Surface Analysis in Conservation”. International Journal of Conservation Science 4 (2013) 535-548.

Tüner-Önen N. \& Akçay A (2014). "Phaselis Kentinin Su Teminine İlişkin Gözlemler ve Dijital Epigrafi 
Çalışmaları”. MJH IV/2 (2014) 279-292. Doi: 10.13114/MJH.201428446

Woodhead A. G. (1981). The Study of Greek Inscriptions. Cambridge \& New York 1981.

Willems G., Verbiest F., Moreau W., Hameeuw H., van Lerberghe K. \& van Gool L. (2005). "Easy and Cost-Effective Cuneiform Digitizing”. Eds. M. Mudge, N. Ryan \& R. Scopigno, The $6^{\text {th }}$ International Symposium on Virtual Reality, Archaeology and Cultural Heritage (VAST'05) (2005) 73-80. Pisa, Italy.

Zányi E., Schroer C., Mudge M. \& Chalmers A. (2007). “Lighting and Byzantine Glass Tesserae”. EVA London Conference 11-13 July 2007: Electronic Information, the Visual Arts and Beyond 22.122.8 (2007) London. 